\title{
Caribou Trail Systems in Northeastern Alaska
}

\author{
ROBERT E. LeRESCHE ${ }^{1}$ and \\ SPENCER A. LINDERMAN ${ }^{2}$
}

\begin{abstract}
Trails left by caribou on their spring, summer and fall ranges persist for many years and therefore provide useful record of patterns of caribou movement. Trails covering $15,000 \mathrm{~km}^{2}$ of northeastern Alaska were mapped from light aircraft, and found to correspond with present patterns of movement of the Porcupine caribou herd. Caribou follow contours in hilly terrain; use gentle slopes and passes; travel in narrower lanes in steep areas; course natural obstacles before crossing them; and follow previous caribou trails. Areas of special importance to caribou because of funnelling of their movements are identifiable from trail maps, which are therefore useful tools in the planning of proposed structures in caribou ranges.
\end{abstract}

RÉSUMÉ. Les réseaux de pistes des caribous dans le nord-est de l'Alaska. Les pistes laissées par les caribous dans leurs aires du printemps, de l'été et de l'automne persistent pendant plusieurs années et donnent une bonne idée du dessin des déplacements de ces animaux. A bord d'avions légers, les auteurs ont survolé des pistes couvrant $15,000 \mathrm{~km}^{2}$ dans le nord-est de l'Alaska et qui correspondent au dessin actuel des déplacements du troupeau de Porcupine. Les caribous suivent les courbes de niveau en terrain montueux, utilisent les pentes douces et les passes, voyagent par des sentiers plus étroits dans les régions escarpées, longent les obstacles naturels avant de les franchir et suivent les pistes plus anciennes. On peut identifier les zones d'importance pour les caribous par la convergence de leurs déplacements, sur des cartes des pistes, qui sont donc des outils précieux pour l'aménagement de structures dans les aires des caribous.

РЕЗЮМЕ. Системъ следов карибу в северо восточной части Аляски. Следы сохраняющегося в течение многих лет неияменны передвижения карибу по весенним, летним и осенним пастбицам дают полевнуго информацию о характере әтого передвижения. C легкого самолета было проведено составление карт следов, соответствующих пути передвижения стада "поркьюпайн " карибу и покрывагои 15 тысяч $\varkappa^{2}$ в северо-восточной части Аляски. В холмистой местности карибу следуют пвогипсам, выбирают пологие склоны и перевалы, в крутых местах двигагося в более узких коридорах, до пересечения естественных препятствий тщательно обследуют их и придерживаются прежних троп. По схождению следов на картах хорошо определяотся напболее важные для карибу места, что делает такие карты полевными при планировании будуших сооруякний в местах пастбищ әтих животных.

\section{BACKGROUND}

An acceleration in the pace of northern development has caused attention to be focused on caribou (Rangifer tarandus) herds in the Arctic and their patterns of movement. Since 1971, the distribution, numbers and movements of the Porcupine herd in northeast Alaska have been considered in studies (Calef and Lortie 1972, 1973; LeResche 1972) designed partially to evaluate alternative routes proposed for a natural gas pipeline from Prudhoe Bay, Alaska, to Edmonton, Alberta. 
Concern exists that man-made structures might function as barriers and inhibit movements of caribou, or at least alter their patterns, to the animals' detriment. Experimental studies (Child 1973; Child and Lent 1973), observational data (Miller et al. 1972) and literature reviews (Klein 1971) have shown that unfamiliar structures may affect the movements of caribou in various ways. The magnitudes and types of effect can vary considerably with season, other environmental factors, and behavioural factors such as habituation and tradition. Nevertheless, all structures studied were found to affect movements at least to some extent. In view of this, some consideration has been given to the possibility of routing new structures (especially pipelines) in such ways as to minimize, or at least reduce, their conflicts with routes of caribou migration.

The changeable nature of the movements and distribution of caribou dooms short-term studies to failure. A review of the literature concerning Alaskan caribou (Murie 1935; Skoog 1968; Hemming 1971) demonstrates amply the highly dynamic nature of caribou movement "patterns." A "pattern" of annual movements that persists throughout the course of a two- or three-year study may prove to be anomalous when reviewed in terms of the period of existence of a pipeline or a road.

For these reasons, the present authors searched for information giving a medium-to-long-term view of patterns of caribou movement. One obvious indicator was trail systems that persist for years on caribou summer ranges. Such trails on the North Slopes and the foothills of the Brooks Range of Alaska east of the Canning River are the subject of this report.

\section{METHOD}

During the period June-August 1972 the present authors mapped caribou trails in the described area at the same time as making records of caribou movements. They observed trails while flying over at approximately $80 \mathrm{~km} / \mathrm{hr}$ in a light aircraft at altitudes of $180-300 \mathrm{~m}$ above the ground. When it was uncertain whether ground patterns did indeed represent caribou trails, the height was reduced to as low as $10-20 \mathrm{~m}$; and ground patterns were often circled at varying altitudes in efforts to take advantage of differences in lighting and reflections. Trails were mapped, immediately after being observed, on U.S. Geological Survey 1:63,360 quadrangles.

Trail patterns were classified in three categories, which represented combinations of such factors as numbers of animals using a route, frequency and recentness of use of the route, and substrate characteristics. The categories were the following:

1) Narrow, heavy trails: very obvious trails, each forming one route of movement, which may be as wide as $100 \mathrm{~m}$, and cannot reasonably be regarded as a series of individual, parallel or braided trails.

2) Wide, heavy trails (See Figs. 1 and 2): very obvious trails some $5-8 \mathrm{~km}$ wide, each composed of a series of parallel or braided, narrow trails.

3) Light trails: scattered indistinct trails, either single, parallel or braided. 


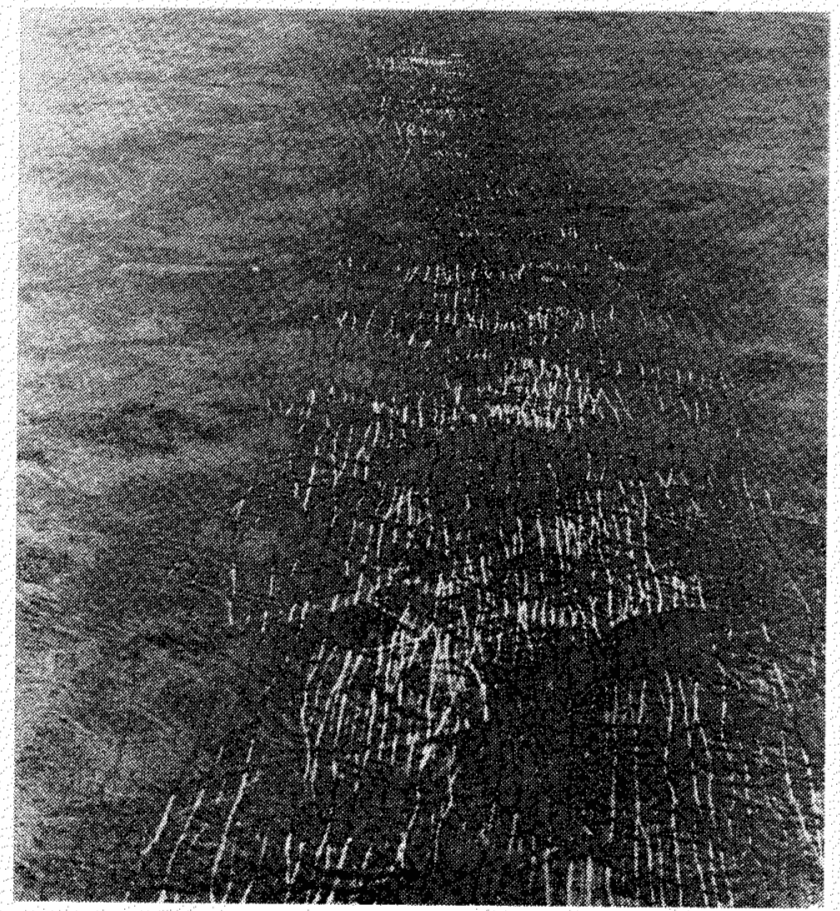

FIG. 1. "Wide heavy trail" on wet meadow.

FIG. 2. Caribou on

"wide heavy trail" on an Eriophorum tussock community near Camden Bay.

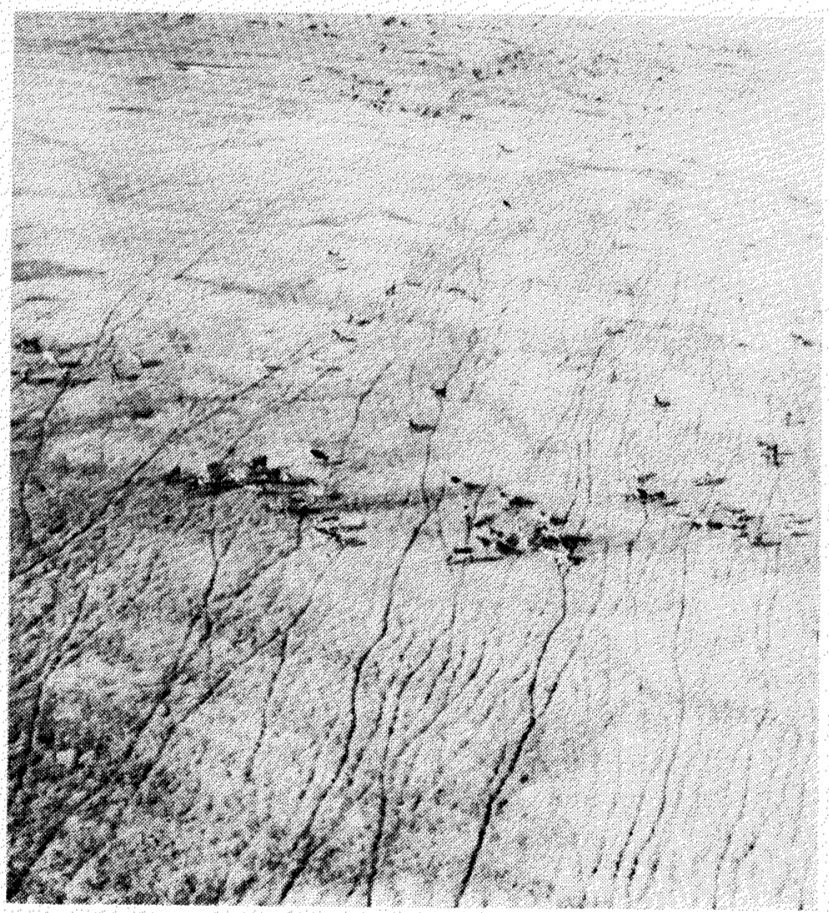




\section{RESULTS}

Twenty-five 1:63,360 quadrangles were prepared detailing trail systems in approximately $15,000 \mathrm{~km}^{2}$ of calving and summer habitat. Major systems mapped in the first two of the three above categories are shown in smaller scale in Fig. 3.

The general pattern of summer movements observed from 1971 to 1973 is illustrated by the trail patterns mapped, but other patterns less easily explained by recent observations are also present.

During recent years, caribou have arrived on the mapped area in late May from the south and east, using the Kongakut and Aichilik River valleys and the foothills just south of the coastal plain. After calving in early June they have moved westward in the foothills, generally following contours in the range 750-1500 feet $(230-460 \mathrm{~m})$. Some animals have travelled as far west as the Canning River before forming large post-calving concentrations. Concentrations of 30,000 to 60,000 animals have formed on the flat benches along the upper Okpirourak River and in the northern foothills of the Sadlerochit Mountains. These concentrations have then moved northwest and northeast to join together on the coastal plain just south of Camden Bay in a tremendous concentration of over 80,000 animals (by actual count) within an area of 80-100 km². On 3 July in both 1972 and 1973 the concentration moved eastward on a broad front extending $25-30 \mathrm{~km}$ inland from the intertidal zone of the Arctic Ocean. The animals moved southeast after crossing the Jago River, and then crossed Aichilik and Egaksrak Rivers, still on a broad front. Animals reaching the mouth of the Kongakut River swung south, funnelling

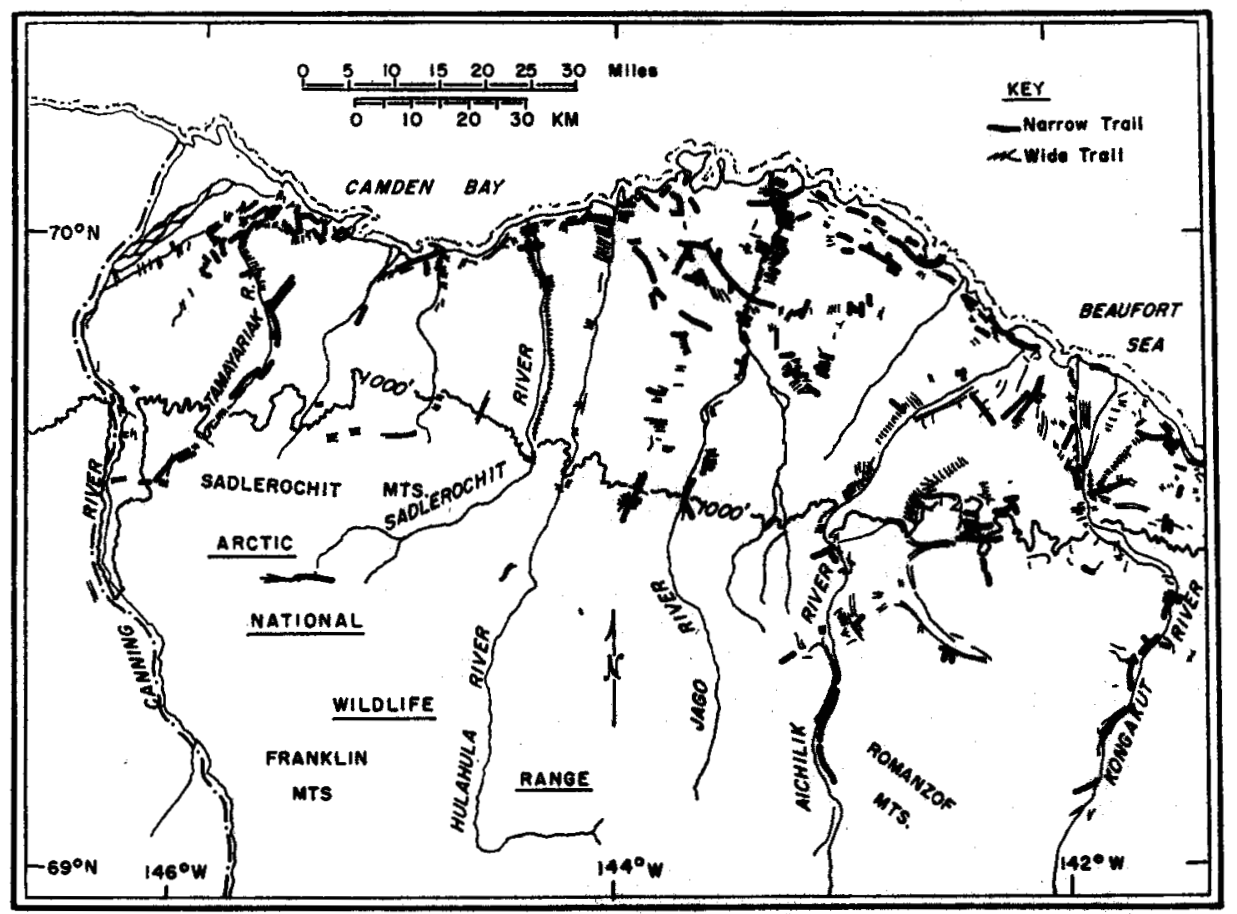

FIo. 3. Major caribou trails in the study area. 
together with those from farther inland. The entire herd crossed the Kongakut north of the Paulaluk River, proceeding eastward into Canada by mid-July.

These movements are well indicated by the trails shown in Fig. 3, which represent a north-south movement through the Brooks Range, an east-west movement in narrow fronts in the foothills, a northerly movement of the concentrations towards Camden Bay, and an extensive broad-front, east-west movement along the coastal plain.

Large-scale maps of trail systems indicate important facets of terrain-following and natural-feature diversions by caribou (Figs. 4 and 5). Trail direction and nature (i.e. single-line or broad-front) vary with steepness, with nature of slopes, and with features such as lakes, rivers, and cut-banks. These patterns of movement occur often enough to allow some prediction of routes caribou will take, but are not so rigidly fixed as to make field checks unnecessary.

The following general principles appear to hold from an examination of trail systems and observations of the caribou:

1) Caribou follow contours in hilly terrain. They traverse side hills rather than move across contours. This tendency is especially evident in the northern foothills of the Brooks Range, where east-west trail systems follow the 750$1500 \mathrm{ft}(230-460 \mathrm{~m})$ contours, and through mountain passes, where caribou often use side slopes as well as valley bottoms.

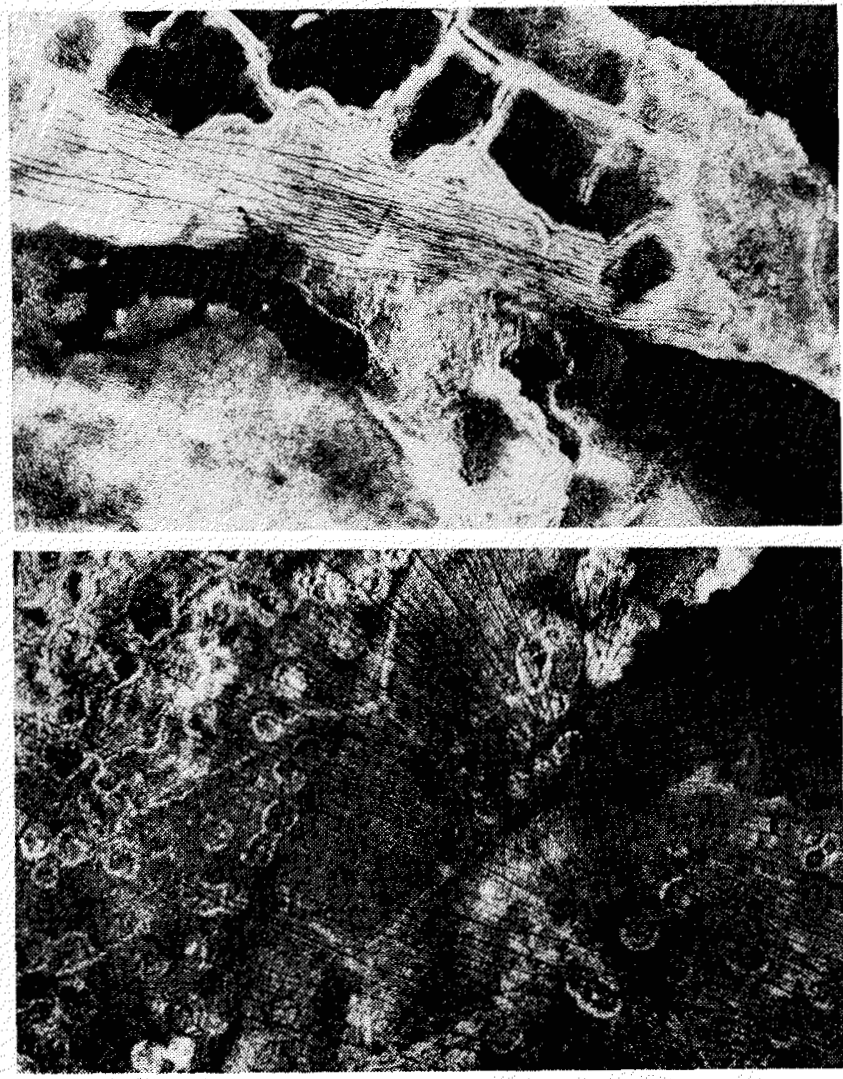

FIG. 4. Wide heavy trail parallelling wet areas that could be easily crossed.

FIG. 5. Funnelling of many trails at the tip of a shallow lake. 
2) When traversing hilly country, caribou usually use ridgelines, the lowest passes and the most gentle slopes. The animals however occasionally traverse steeper terrain, for unknown reasons.

3) Caribou tend to travel in narrower lanes when in steep areas, and to spread out on a broader front when in flat areas.

4) Caribou tend to course natural features (e.g. rivers, steep slopes, cut-banks) for some distance before crossing them. This appears to be true regardless of how easily the features might be crossed at the point of first encounter (Fig. 4).

5) Caribou trails themselves are important terrain features, and as such affect the animals' movements. That is, caribou will tend to follow almost the exact path of a preceding group of animals, even in areas of almost featureless terrain. The more recent the preceding movement, the more likely the succeeding group is to follow it. As a result, precise routes travelled by groups of caribou probably vary more from year to year than within a given year.

6) The above factors combine to cause a funnelling of caribou between or along topographical features that form obstacles, or else are below the optimum level of routes for caribou (Figs. 4 and 5). These areas of funnelling are therefore critical ones for caribou movements.

\section{DISCUSSION}

Trail patterns in the eastern parts of the North Slope and Brooks Range demonstrate almost total use of this area by caribou in the past. Animals of the Porcupine caribou herd currently use this area as a calving ground and summer range; therefore trail maps of it disclose little new information regarding the general presence of caribou. Trail maps do however provide insight into specific routes used at specific sites, and may thus be useful in the planning of any structures that may be considered in the future. In addition, they do show specific routes used in the past, but not during the last two years.

For example, were a barrier such as a road, a railroad, an elevated pipeline or a powerline to be built in an east-west direction across the area mapped, caribou movements would be least affected were construction to take place in certain locations. Generally, a route north or south of the major zone of caribou trails would be preferable - for example, along the coast or in the foothills above $1000 \mathrm{~m}$ in elevation. Once the general route was chosen, particular routings could be made to take into account specific trail patterns. An optimum design would be one which allowed for parallel trails where possible, and provided crossing features at points where trails and structure intersected. The structure should avoid entirely areas where caribou from a broad front were funnelled into a narrow trail, and if it were made to follow features that are natural barriers ordinarily coursed by caribou (e.g., cut-banks, swift sections of large rivers, and steep hillsides) additional blocking effects would be minimized, provided crossings were constructed at the most natural locations for them.

The present authors hope that the technique of mapping trails from aerial 
photographs, as described above, will be used in the future when man-made structures must be designed to accommodate the movement of caribou. They have used caribou and moose trail patterns as an aid to the designing of the Trans-Alaska Oil Pipeline and for the purposes of commenting upon development plans for the Prudhoe Bay oil field. Since long-term intensive studies of the behaviour of large mammals are impracticable over areas as large as those affected by these projects, trail maps are often the only means available to estimate movement patterns. In addition, some areas (e.g. east-central Alaska and western Alaska) are not at present fully used by caribou, though they have been in the past and could be in the future. Trail patterns in these areas are especially useful in the reconstruction of patterns of movement.

The technique is basically a subjective recording of signs left by past events on a very variable and unstable substrate. As such, it involves two major problems: that caribou leave visible trails in some places more readily than in others; and that trails persist in some areas longer than in others. The types of trails that will appear, and how long they will persist, are products of soil type, slope, aspect, water content, numbers of caribou using them, frequency of use, caribou behaviour (e.g. milling, walking), time of year, and probably other factors (Benninghoff 1952; Hok 1969; Pegau 1970). As such, the technique cannot be expected to indicate frequency of use, recentness of use, or intensity of use of a given caribou trail. In fact, the absence of trails amounts to no sure proof that an area is unimportant to caribou, although consideration of general soil and vegetation types and general seasonal movements in the area provides indications in most cases. Further, it should be remembered that this technique applies only to spring, summer, and autumn movements of groups of caribou. Other areas important during August dispersal and in winter should be evaluated by other means. What employment of the technique does show is where caribou have been in the past. For this reason alone it is a valuable tool in the evaluation of construction plans in areas where intensive or long-term study has not been possible.

\section{ACKNOWLEDGEMENTS}

This study was financed by Federal Aid in Wildlife Restoration Project W-17-5 (Alaska). Averill Thayer, Manager, Arctic National Wildlife Range, allowed use of U.S. Fish and Wildlife Service facilities during the work reported. Figs. 4 and 5 were provided by Mr. T. Hazard, U.S. Bureau of Land Management.

\section{REFERENCES}

BENNINGHOFF, W. S. 1952. Interaction of vegetation and soil phenomena. Arctic, 5(1): 34-44.

CALEF, G. W. and LORTIE, G. M. 1972. Observations of the Porcupine Caribou Herd: April 1September 22, 1971. Winnipeg, Manitoba: Environmental Protection Board. 46 pp.

Environmental Protection Board. $127 \mathrm{pp}$.

CHILD, K. N. 1973. The Reactions of Barren-ground Caribou to Simulated Pipeline and Pipeline Crossing Structures at Prudhoe Bay, Alaska. College, Alaska: Alaska Cooperative Wildlife Research Unit. 49 pp. 
CHIID, K. N. and LENT, P. C. 1973. The Reactions of Reindeer to a Pipeline Simulation at Penny River, Alaska. Interim Report. College, Alaska: Alaska Cooperative Wildlife Research Unit. 30 pp.

hemMing, J. E. 1971. The distribution and movement patterns of caribou in Alaska. Alaska, Department of Fish and Game Wildlife, Technical Bulletin no. 1.60 pp.

HOK, J. R. 1969. A reconnaissance of tractor trails and related phenomena on the North Slope of Alaska. U.S., Department of the Interior, Bureau of Land Management. $66 \mathrm{pp}$.

KLEIN, D. R. 1971. Reaction of reindeer to obstructions and disturbances. Science, 173: 393-8.

LERESCHE, R. E. 1972. The international herds: present knowledge of the Fortymile and Porcupine caribou herds. Proceedings of the 1st International Rangifer Symposium, University of Alaska, College, Alaska. pp. 127-39.

MILLER, F. L., JONKEL, C. J. and TESSIER, G. D. 1972. Group cohesion and leadership response by barren-ground caribou to man-made barriers. Arctic, 25(3): 193-202.

MURIE, O. J. 1935. Alaska-Yukon caribou. North American Fauna, 54: 1-93.

PEGAU, R. E. 1970. Effect of reindeer trampling and grazing on lichens. Journal of Range Management, 23(2) 95-97.

SKOOG, R. O. 1968. Ecology of the caribou (Rangifer tarandus granti) in Alaska. (Unpublished Ph.D. thesis, University of California, Berkeley, California). 